\title{
Employer Rights Against Worker Involuntary Servitude
}

\author{
Sachin S. Pandya ${ }^{\dagger}$
}

This article argues that employers can sometimes validly challenge laws as violating the Thirteenth Amendment's Involuntary Servitude Clause. Judges currently read that clause to bar some kinds of physical or legal coercion against workers who would otherwise quit their current employer. This paper identifies how existing Involuntary Servitude Clause doctrine can be extended to bar legal coercion against prospective employers who would otherwise hire those workers after they quit. If so extended, the Involuntary Servitude Clause would set a minimum level of labor mobility in the United States. To illustrate, the article discusses how employers can use the Involuntary Servitude Clause to challenge (1) labor mobility restrictions on $\mathrm{H}-2$ foreign guest workers, and (2) non-competition clauses in labor contracts.

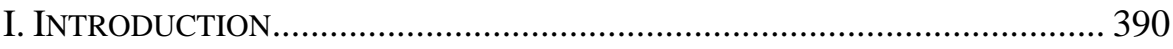

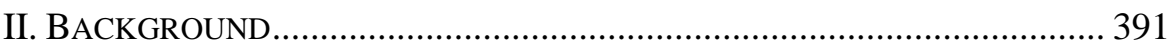

A. Bailey v. Alabama ............................................................ 391

B. Post-Bailey Employer Cases ............................................... 393

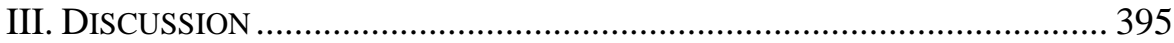

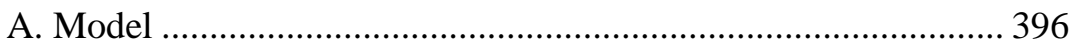

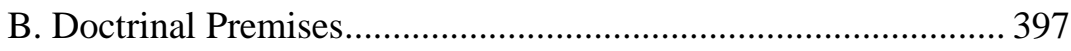

1. Criminal Sanctions .............................................................. 398

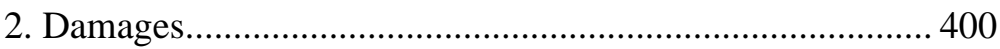

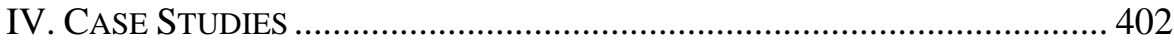

A. Case Study: H-2 Workers....................................................... 403

B. Case Study: Non-Competition Agreements .............................. 411

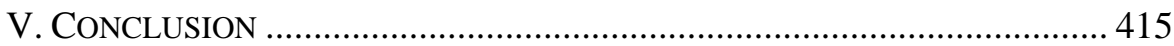

$\dagger$ Professor of Law, University of Connecticut (http://orcid.org/0000-0001-7387-1307). (C) 2020 Sachin S. Pandya. This work is available after publication under a CC-BY-NC-ND 4.0 license. For comments on prior drafts, thanks to Jon Bauer, Ayesha B. Hardaway, Maria L. Ontiveros, James Gray Pope, Peter Siegelman, and Rebecca E. Zietlow. 


\section{INTRODUCTION}

Since Bailey v. Alabama (1911), courts have read the Thirteenth Amendment's Involuntary Servitude Clause to ban not just traditional forms of peonage, but also most laws that, upon the threat of criminal sanction, coerce workers into staying with their current employers when they would otherwise quit. ${ }^{1}$ This paper shows how this doctrine can extend to laws that restrict employer hiring of workers who quit. So read, the Involuntary Servitude Clause provides a minimum level of labor mobility that protects not just workers, but also the employers who might hire them.

The core idea is simple. If a law makes it a crime for you to quit, you would be far less likely to quit as a result. That is why most such laws, under Bailey and its progeny, violate the Involuntary Servitude Clause. Now, suppose a law makes it a crime for anyone to hire you after you quit. You will not go to prison for quitting, but anybody who hires you could. Therefore, you fear that if you do quit, no one would risk prison to hire you. Thus, the law makes you less likely to quit, perhaps just as much as if the law had made quitting itself a crime. If so, this law, though it restricts only employers, not workers, should also violate the Involuntary Servitude Clause.

This is an old idea, but the commentary on the Involuntary Servitude Clause $^{2}$ has largely ignored what it implies: Employers may themselves challenge a law as violating the Involuntary Servitude Clause insofar as that law, by limiting or restricting their hiring, thereby affects worker quits. This implication can especially matter when workers are too poor or fearful to enforce their legal rights. Employers, by contrast, have more resources and more commercial incentive, especially in tight labor markets, to invoke legal process to protect their ability to hire workers away from their business rivals.

In turn, this idea should lead lawyers and judges to rethink how they argue about or decide the merits of Involuntary Servitude Clause claims. As explained below, Bailey and its progeny largely turn on what judges assume about how much a law aims at or affects a worker's probability of quitting.

1. Bailey v. Alabama, 219 U.S. 219 (1911); accord Pollock v. Williams, 322 U.S. 4 (1944); see also United States v. Kozminski, 487 U.S. 931, 943 (1988) (collecting cases); see generally Ann K. Wooster, Annotation, Application of Section 1 of 13th Amendment to United States Constitution, U.S. Const. Amend. XIII, § 1, Prohibiting Slavery and Involuntary Servitude-Labor Required by Law or Force Not as Punishment for Crime, 88 A.L.R. 6th 203 (2013 \& Supp. 2019) (collecting cases). For exceptions, see Kozminski, 487 U.S. at 944; Wooster, supra § II(B)(3).

2. See, e.g., James Gray Pope, Contract, Race, and Freedom of Labor in the Constitutional Law of Involuntary Servitude, 119 YALE L. J. 1474 (2010); Nathan B. Oman, Specific Performance and the Thirteenth Amendment, 93 MinN. L. REV. 2020 (2009); Todd D. Rakoff, Enforcement of Employment Contracts and the Anti-Slavery Norm, in HuMAN RIGHTS In PRIVATE LAW (Daniel Friedmann \& Daphne Barak-Erez eds., Hart Publishing Co. 2001); Robert J. Steinfeld, Coercion, Contract, AND Free Labor In the Nineteenth Century (2001); Benno C. Schmidt, Principle and Prejudice: The Supreme Court and Race in the Progressive Era. Part 2: The Peonage Cases, 82 Colum. L. Rev. 646 (1982); Howard Devon Hamilton, The Legislative and Judicial History of the Thirteenth Amendment, 10 NAT'L B. J. 7 (1952). 
In such challenges, a judge, in deciding claim merits, usually considers only how a law directly affects worker quits. In fact, that judge should also consider how much that law also affects worker quits by restricting new employer hiring. This simple insight can make the difference in suits challenging laws as violating the Involuntary Servitude Clause.

The article proceeds as follows. Part II describes how Bailey and its progeny read the Involuntary Servitude Clause. Part III identifies the core factual premises of this doctrine and considers how well those premises extend to employers. Part IV offers two case studies to illustrate of how employers could extend those doctrinal premises to challenge labor mobility restrictions: (1) legal restrictions on the labor mobility of H-2 temporary foreign guest workers during their authorized stay in the U.S. and (2) noncompetition agreements that restrict where, when, or for whom a person may work after they quit their current employer. There, the article shows how employers can argue that the Involuntary Servitude Clause at least (1) requires federal immigration law to let $\mathrm{H}-2$ workers quit and work for a new employer in the U.S. while a new H-2 visa petition for those workers is filed and pending; and (2) precludes injunctive relief to enforce non-competition agreements.

\section{BACKGROUND}

The Thirteenth Amendment prohibits the condition of "involuntary servitude" by declaring that it shall not "exist within the United States, or any place subject to their jurisdiction."” This section briefly discusses how courts applied the Involuntary Servitude Clause in Bailey v. Alabama and its progeny. ${ }^{4}$

\section{A. Bailey v. Alabama}

In Bailey v. Alabama (1911), Alonzo Bailey had been indicted for violating an Alabama criminal fraud statute by agreeing to work as a farmhand for one year for the Riverside Company, taking a fifteen-dollar cash salary advance, and quitting a few months into the one-year contract term. ${ }^{5}$ Although the prosecution nominally had the burden of proving Bailey's intent to commit fraud when he agreed to the one-year contract and

3. U.S. CONST. amend. XIII, $\S 1$.

4. This doctrine, see supra note 1, arose in reaction to state laws, adopted particularly in the South in the late 19th and early 20th century, largely to restrict the mobility of black workers, particularly in agriculture. See generally WILLIAM COHEN, AT FREEDOM's EDGE: BLACK MOBILITY AND THE SOUTHERN White QUEST FOR RACIAL CONTROL, 1861-1915 (1991); Jennifer Roback, Southern Labor Law in the Jim Crow Era: Exploitative or Competitive?, 51 U. CHI. L. REV. 1161 (1984).

5. Bailey, 219 U.S. at 228-31; Indictment, State v. Bailey, in Transcript of Record at 1, Bailey v. Alabama, 219 U.S. 219 (1911) (No. 300). 
took the cash advance, the statute included a legal presumption that a defendant had the requisite intent if the prosecutor proves that the defendant had taken money or property (here, the cash advance) from the employer and then failed to perform the promised labor or failed to refund the employer. ${ }^{6}$ Thereafter, Bailey's lawyers tried and failed to dismiss the prosecution on several grounds, including that the statute in effect subjected Bailey to involuntary servitude in violation of the Thirteenth Amendment. ${ }^{7}$ A jury convicted Bailey, after which Bailey's lawyers challenged the conviction, ultimately arguing to the U.S. Supreme Court that the statute, by operation of its presumption, subjected Bailey to "involuntary servitude" prohibited by the Thirteenth Amendment, because the statute thereby let "the employer or landlord ... send to hard labor or jail the employe [sic] or tenant who refuses or fails to discharge the obligations under the contract."

The Court agreed. By effectively exposing to criminal conviction anyone who failed or refused to perform a personal-service contract "in liquidation of a debt, and, judging its purpose by its effect," the statute thereby provided "the means of compulsion through which performance of such service may be secured."

First, the Court reasoned that it mattered that the challenged statute "authorizes the jury to convict," regardless of whether the jury may refuse to convict nonetheless. ${ }^{10}$ Thus, "in considering the natural operation and effect of the statute," the Court explained that it could consider how the statute affected not just Bailey, but also anyone and everyone else that the statute authorized a jury to convict. ${ }^{11}$

Second, the Court read the Involuntary Servitude Clause to prohibit "control by which the personal service of one man is disposed of or coerced for another's benefit."12 Although Alabama's statute did not enforce traditional peonage, it sufficed that the statute, "through the guise of contracts under which advances had been made," compelled those workers to keep on working, thereby creating "the condition of servitude ..., which would be not less involuntary because of the original agreement to work out the

6. Bailey, 219 U.S. at 228 (quoting $§ 4730$ of Ala. Code of 1896, as amended) (“" And the refusal or failure of any person who enters into such contract to perform such act or service or to cultivate such land or refund such money or pay for such property without just cause shall be prima facie evidence of the intent to injure his employer or landlord or defraud him."').

7. Motion to Quash Indictment, State v. Bailey, in Transcript of Record at 3-4, Bailey v. Alabama, 219 U.S. 219 (1911) (No. 300).

8. Brief for Plaintiff in Error at 33, Bailey v. Alabama, 219 U.S. 219 (1911) (No. 300). On the Bailey litigation's origins, see Pete Daniel, Up from Slavery and Down to Peonage: The Alonzo Bailey Case, 57 J. Am. Hist. 654 (1970).

9. Bailey, 219 U.S. at 241.

10. Id. at 235 .

11. Id.

12. Id. at 241 . 
indebtedness. The contract exposes the debtor to liability for the loss due to the breach, but not to enforced labor." 13

Third, the Court found that challenged statute supplied the requisite compulsion because it authorized criminal sanctions. By its "natural operation," and regardless of "any actual motive to oppress," employers and others could use the statute "to hold over the heads of laborers the threat of punishment for crime, under the name of fraud, but merely upon evidence of failure to work out their debts." 14 The resulting fear of criminal sanction was enough to compel workers to keep working; it was "more powerful than any guard which the employer could station."15

In dissent, Justice Holmes criticized the majority opinion's key distinction between the effect of a law with criminal sanctions and that of civil liability for contract damages. Both "tend[] to make the contractor do as he said he would. ... [I]f a state adds to civil liability a criminal liability to fine, it simply intensifies the legal motive for doing right; it does not make the laborer a slave."16 Similarly, Holmes argued that although "liability to imprisonment may work as a motive when a fine without it would not, and that it may induce the laborer to keep on when he would like to leave[,] . . . it does not strike me as an objection to a law that it is effective." 17

\section{B. Post-Bailey Employer Cases}

While many workers have invoked Bailey and its progeny to challenge laws as unduly discouraging quitting, ${ }^{18}$ it is less well known that, in a few cases, employers relied on Bailey to avoid liability under state enticement laws. Enticement law imposed damages liability and (sometimes) criminal fines against employers who induced or enticed workers, often black sharecroppers, to quit their current employer or landlord and work for them instead, where quitting would breach the worker's contract with their (former) employer. ${ }^{19}$ In the $1920 \mathrm{~s}$, faced with post-Bailey challenges to damages awards for enticement, two state supreme courts (South Carolina

13. Id. at 242 .

14. Id. at 245 .

15. Id. at 244 (citation and internal quotation marks omitted).

16. Id. at $246-47$.

17. Id. at 247 .

18. See Wooster, supra note 1.

19. COHEN, supra note 4, at 31-33. For enticement statutes still on the books, see MISS. CODE ANN. § 97-23-29; see also N.C. GEN. STAT. § 14-358. Such statutes thus went beyond the common-law tort claim for enticement. C.B. LABATT, 7 COMMENTARIES ON THE LAW OF MASTER AND SERVANT 8067-94 (2d ed. 1913). And some evidence suggests that enticement statutes in fact restricted worker mobility. E.g., Suresh Naidu, Recruitment Restrictions and Labor Markets: Evidence from the Postbellum U.S. South, 28 J. LAB. ECON. 413, 425 (2010). 
and Mississippi) read their law to require something beyond hiring a worker while knowing that worker to have quit in breach of contract.

In Shaw v. Fisher (1920), the South Carolina Supreme Court reversed a jury verdict for tort damages and ordered a new trial in a case against the defendant for hiring Carver, a sharecropper who had quit the plaintiff's employ in breach of his labor contract. ${ }^{20}$ The court reasoned that, given the jury instructions, the jury may have held the defendant liable not for enticing Carver away from the plaintiff, but just for hiring Carver while knowing that Carver had "of his own volition" breached his contract with the plaintiff, his former employer. ${ }^{21}$ The defendant-employer's tort liability on that basis, without more, raised a Thirteenth Amendment problem: If no employer like the defendant could have employed Carver without incurring damages liability, "the result would have been to coerce him to perform the labor required by the contract; for he had to work or starve. The compulsion would have been scarcely less effectual than if it had been induced by the fear of punishment under a criminal statute for breach of his contract." 22

A few years later, the Mississippi Supreme Court decided Thompson $v$. Box (1927). ${ }^{23}$ There, the plaintiff (a worker's former employer) had sued the defendant (that worker's current employer) for damages under a Mississippi statute that imposed liability on anyone who "shall willfully interfere with, entice away, or who shall knowingly employ, or who shall in any manner induce" a worker with a fixed-term contract to quit his current employer before the contract expired, absent his current employer's written consent. ${ }^{24}$ After the plaintiff testified, the trial court granted the defendant's motion for a directed verdict and, on appeal, the Mississippi Supreme Court affirmed the judgment. ${ }^{25}$ Following Bailey, that court reasoned that if someone like the defendant faced statutory liability for "knowingly employ[ing]" a laborer who had left his former employer before the contract expired, then

by practical application, the mind of the laborer would not be free to breach his contract ... . He must 'stay or starve,' because no one could employ him until he had made investigation and found that such laborer or tenant had good cause to leave the leased premises, because the employer or landlord had first breached the contract. ${ }^{26}$

The court then purported to read the statute to avoid this result: The defendant had "acted in good faith in believing that the negroes [i.e., the workers he had hired] had abandoned their contract, and abandoned the

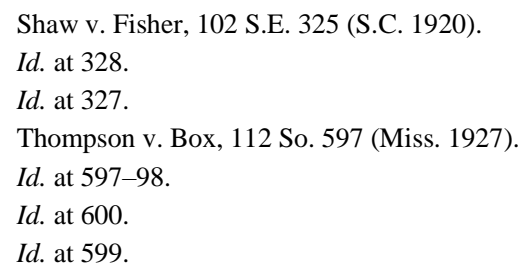


premises of their former employer, and, so believing, contracted with them, and in so doing did not render himself liable to any penalty imposed by this statute." 27

Commentators have not been kind to Thompson, ${ }^{28}$ and Shaw also stressed a hiring employer's constitutionally protected liberty of contract. ${ }^{29}$ Nonetheless, and regardless of their current value, if any, as precedent, both Shaw and Thompson are worth noting. They extended Bailey to reason that, absent a limiting construction, laws authorizing damages against hiring employers would, as a result, unduly coerce workers to stay when they would otherwise quit, and that would violate the Involuntary Servitude Clause. Some have noted this feature of Shaw and Thompson, but without going much further. ${ }^{30}$

\section{DISCUSSION}

This paper's key contribution is to show how lawyers and judges can extend Bailey and its progeny's key factual premises to laws that regulate employer hiring, and thereby read the Thirteenth Amendment's Involuntary Servitude Clause to impose a minimum level of labor mobility. To see why and how, we will start with a simple model of how laws can affect worker quits. This model depicts a simple intuition: Any law can affect worker quits not only by exposing workers to adverse legal consequences for quitting, but also by attaching adverse legal consequences to new employers for hiring those workers, or by causing those workers to change their job-search scope. After setting up the model, we will compare its assumptions to the factual premises embedded in Bailey and its progeny, which are mostly cases where the challenged law directly restricts worker quits. Finally, we will assess how well those premises extend to a challenged law that restricts employer hiring.

27. Id. at 600 .

28. Hamilton, supra note 2, speculated that the Thompson court's gloss on the statute still left the statute on the books where it exerted the same "intended compulsion" as before. Similarly, Novak suggested that workers, employers, or local justices of the peace would likely be unaware of the Thompson court's limiting construction, and, with the statutory text unchanged, the statute's coercive effect "continue[d] as usual except where decisions were appealed." DANIEL A. NOVAK, THE WHEEL OF Servitude: Black ForCed Labor After Slavery 70 (1978). For similar reasons, McMillen called Thompson a "masterpiece of obfuscation" that "seemed to invalidate restrictive labor practices even as it upheld a restrictive labor law.” NEIL R. MCMILLEN, DARK JouRNEY: BLACK MisSisSiPPIANS IN THE AGE OF JIM CROW 144 (1989).

29. See Shaw, 102 S.E. at 327 .

30. E.g., STEINFELD, supra note 2, at 288-89. At best, Pope, supra note 2, at 1531-33, stressed Shaw's stay-or-starve reasoning as ballast for a worker's right under the Involuntary Servitude Clause not only to quit, but also to change employers. 


\section{A. Model}

Consider a simple model in which the probability of quits by a given population of workers can be affected by (1) the challenged law; (2) the probability of whether those workers will get a new job if they quit; and (3) those workers' job-search scope, i.e., the workers' occupational, industrial, geographic, wage-level, and other preferences that affects the size of the pool of potential jobs for which the worker searches. Let Q denote the probability of worker quits; let $\mathrm{X}$ denote whether the challenged law exists; and let $\mathrm{J}$ denote the probability a new employer hires the workers. For simplicity, assume that each of our workers always accurately estimates the probability that the new employer would hire them. Finally, let $\mathrm{S}$ denote the quitting workers' job-search scope, which is already determined by some function of worker preferences (e.g., geography, job type, industry). To make it simple, we can think of that scope as a continuous variable that runs from no search at all to a worldwide search for any job $(S=[0,1])$.

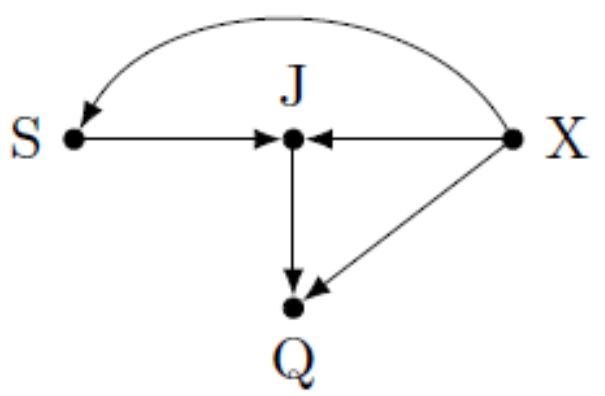

Figure 1

Figure 1 depicts assumptions about how these variables relate. We assume that the worker's estimate of the odds that a new employer would hire them affects their probability of quitting $(J \rightarrow Q)$. We also assume that a worker's job-search scope affects the odds that a new employer would hire that worker $(S \rightarrow J)$. If the worker searches for a new job in only one industry, or only in, say, a twenty-mile area surrounding their current home, then that person is thereby less likely to get a new job as compared to someone searching nationwide or worldwide for a job in any industry, and thus, less likely to believe that they will get a new job. In this way, a worker's jobsearch scope can ultimately affect the probability that a worker quits their current job $(S \rightarrow J \rightarrow Q)$.

We also assume that the challenged law $(X)$ affects worker quits by (a) directly exposing a set of workers to adverse legal consequences for quitting $(X \rightarrow Q)$; or (b) attaching adverse legal consequences to new employers for 
hiring those workers $(X \rightarrow J \rightarrow Q$ ); or (c) causing the worker to change their job-search scope $(X \rightarrow S \rightarrow J \rightarrow Q)$.

Path (a) corresponds to the facts of Bailey: The law at issue in that case exposed people like Bailey to criminal sanctions for quitting before their labor contract's fixed term expired. Path (b) corresponds to the facts of Shaw and Thompson. The laws at issue in those cases exposed new employers to liability for hiring certain workers, and thus made it less likely that those employers would hire those workers. That in turn, Shaw and Thompson assumed, reduced the probability that such workers would quit in the first place.

Given these assumptions, we could try to estimate how much a challenged law affects worker quits, all else equal, by calculating the difference in worker quit probabilities in a world with the challenged law and in the counterfactual world without that law. We do not, however, have the data to regularly estimate this effect properly. ${ }^{31}$ Just as importantly, many would disagree over how large that difference must be in order to declare that the challenged law violates the Involuntary Servitude Clause.

\section{B. Doctrinal Premises}

Instead of trying to directly estimate how much a challenged law affects worker quits, lawyers and judges have necessarily relied on the premises embedded in Bailey and its progeny about when a challenged law unduly coerces workers not to quit. This is not unique to Involuntary Servitude Clause doctrine. In constitutional law generally, judges often rely on factual premises to apply a constitutional rule or justify the content of the rule itself. ${ }^{32}$ The sources of such factual premises vary, and can include judges' beliefs and experiences, facts asserted in party and amicus briefs, and sometimes materials outside the record. Later judges then rely on those same factual premises when applying the legal rule or standard that the prior opinion declares. Those judges embed those premises to the extent they take them as both true and binding under the norms of precedent and stare decisis, and thus not rebuttable with contrary evidence in any case. Those judges extend those factual premises to the extent they rely on them to decide new cases involving new situations that arguably comport with arguments (articulable if not articulated) for taking those factual premises as true.

31. The U.S. Bureau of Labor Statistics (BLS) does not cover agricultural establishments or provide state or local-level estimates of job quits in its Job Openings and Labor Turnover Survey. See U.S. Bureau OF LABOR Statistics, HandBook OF Methods ch. 18, 3 (2013), http://www.bls.gov/opub/hom/pdf/homch18.pdf. BLS discontinued a similar survey of State-level labor turnover in 1981. See Katherine Bauer, Examination of State-Level Labor Turnover Survey Data, MONTHLY LAB. REV. 1 (Jan. 2014).

32. DAVid L. FAigman, Constitutional Fictions: A Unified THEORY of Constitutional FACTS 47-56 (2008). 
Accordingly, for any challenged law, the reasoning in Bailey and its progeny contains at least two core premises:

1. If the challenged law effectively authorizes criminal sanctions against workers for quitting, then we must assume that, in the run of cases that law covers, that law tends to adversely affects worker quits enough to create "involuntary servitude."

2. If the challenged law authorizes only contract damages against a worker for quitting, then we must assume that, in the run of cases that law covers, that law tends not to adversely affect worker quits enough to create "involuntary servitude."

These premises arise from the Bailey's key distinction between the effect of a law authorizing criminal sanctions and that of civil liability for contract damages. ${ }^{33}$ Do these premises extend to laws that restrict employer hiring? Shaw and Thompson seem to imply as much, but the opinions in those cases did not directly tackle this question. Accordingly, we will now examine each premise more closely and see how it may justifiably extend to actual or prospective new employers.

\section{Criminal Sanctions}

If the challenged law in effect authorizes criminal sanctions against workers for quitting, we assume that law discourages worker quits to such a degree as to create "involuntary servitude," regardless of how likely it is that such workers will be actually charged or convicted under that law. ${ }^{34}$ Under this premise, we do not care about the potential size of the criminal sanction (e.g., a small fine, one day in jail or 100 days in jail, or a restitution order) or how likely those subject to a challenged law will violate it. In the limiting case, the premise applies even if no prosecutor has ever charged anyone under the challenged criminal law.

33. For this distinction in Bailey, see supra notes 13-17 and accompanying text.

34. See, e.g., People v. Lavender, 398 N.E.2d 530, 533 (N.Y. 1979) (Thirteenth Amendment violated by administrative rule making it a misdemeanor to abandon or willfully fail to perform, without justification, a home improvement contract, because it is "directed ... solely at the failure to perform the services necessary to carry out the contract"); State v. Brownson, 459 N.W.2d 877, 880-81 (Wis. Ct. App. 1990) (same, adopting reasoning of People v. Lavender); Vinluan v. Doyle, 60 A.D.3d 237, 247-49 (N.Y. App. Div. 2009) (finding Involuntary Servitude Clause violation where indictment of nurses for endangerment of children and the physically disabled "makes the nurses' conduct in resigning their positions a component of each of the crimes charged," thereby having the "practical effect of exposing the nurses to criminal penalty for exercising their right to leave their employment at will"). 
In published opinions, some judges seem to extend this premise to specific performance of personal service contracts. ${ }^{35}$ The most plausible justification for doing so is that failure to obey a specific performance order exposes one to criminal sanctions for contempt, which thereby puts injunctions into the class of laws that trigger criminal sanctions. ${ }^{36}$

Today, it still makes sense to focus on whether the challenged law authorizes criminal sanctions, rather than try to estimate how likely convictions are under that law. Studies of criminal risk perceptions indicate that, in general, people tend to poorly estimate the probability of prosecution and conviction under any criminal statute. ${ }^{37}$ Moreover, the probability of conviction depends on the probability of getting prosecuted, which tends to be low if that law, just by being on the books, already deters some people from violating that law. Furthermore, even low-penalty crimes may carry not only the social stigmas or dishonor associated with criminal prosecution and conviction, but also other collateral adverse consequences, such as making it harder to get a job or a bank loan. ${ }^{38}$ Accordingly, it remains justifiable to distinguish, as Bailey does, between criminal and civil sanctions while ignoring the precise severity of those sanctions in any particular case.

These reasons - for focusing only on whether the challenged law authorizes criminal sanctions - apply to employers as well as workers, with two caveats. First, many employers are corporations or other non-natural persons. Accordingly, any fear of criminal sanction is mediated by the rules

35. Beverly Glen Music v. Warner Communications, 224 Cal. Rptr. 260, 261 (Cal. Ct. App. 1986) (stating in dicta that, because of the Involuntary Servitude Clause, "[a]n unwilling employee cannot be compelled to continue to provide services to his employer either by ordering specific performance of his contract, or by injunction") (citation omitted); accord State v. Brownson, 459 N.W.2d 877, 881 n. 4 (Wis. Ct. App. 1990); see also Read v. Wilmington Senior Ctr., Inc., No. C.A. No. 12586, 1992 WL 296870 at *1 (Del. Ch. Sept. 16, 1992) (refusing order individuals to take part in musical performance because it would "compel involuntary servitude"); Callaghan v. Department of Fire, 385 So.2d 25, 27-28 (La. Ct. App. 1980) (reversing city civil-service commission order that, as a penalty, reinstated firefighter must work for 24-hour period without pay, because "[f]orcing a man to work against his will and without pay is involuntary servitude"); see generally Wooster, supra note $1, \S \mathrm{II}(\mathrm{B})(2)(18)$ (collecting cases). Oman, supra note 2 , however, argues that such reasoning is inconsistent with the intent of those who drafted, voted for, or ratified the Thirteenth Amendment.

36. Robert S. Stevens, Involuntary Servitude by Injunction: The Doctrine of Lumley v. Wagner Reconsidered, 6 CORNELL L. Q. 235, 248 (1921); cf. Franks v. Rankin, Nos. 11AP-934, 11AP-962, 2012 WL 1531031, at *14-15 (Ohio Ct. App. May 1, 2012) ("threatened legal sanction [for contempt of court] renders unconstitutional the provision of the preliminary injunction order that requires Rankin to remain as president of CSI"); State ex rel. Carriger v. City of Gallon, 560 N.E.2d 194 (Ohio 1990) (trial judge order that indigent criminal defendants work to pay for appointed counsel is involuntary servitude). But cf. Moss v. Superior Court, 950 P.2d 59, 67 (Cal. 1998) (child support order "does not bind the parent to any particular employer or form of employment or otherwise affect the freedom of the parent").

37. Robert Apel, Sanctions, Perceptions, and Crime: Implications for Criminal Deterrence," $29 \mathrm{~J}$. Quantitative CRIMINOlogy 67 (2013); see also Aaron Chalfin \& Justin McCrary, Criminal Deterrence: A Review of the Literature, 55 J. ECON. LITERATURE 5, 10-12 (2017).

38. See generally David S. Kirk \& Sara Wakefield, Collateral Consequences of Punishment: A Critical Review and Path Forward, 1 ANN. Rev. CRIMINOLOGY 171 (2018). 
that attribute the illegal conduct of the employing entity to the human beings who would face criminal sanctions for acting illegally on the entity's behalf. Second, unlike individual workers, employers often carry liability insurance for themselves and their directors and officers. Such insurance tends to exclude indemnification for criminal convictions but may cover the litigation-related costs of defending against criminal prosecution. ${ }^{39}$

\section{Damages}

Bailey's second core premise is this: If the challenged law authorizes contract damages against a worker for quitting, the worker does not thereby suffer involuntary servitude, regardless of the expected value of any such damages claim. This premise derives from the U.S. Supreme Court's distinction between traditional peonage and a contract to work to pay off a debt: "[T] he debtor, though contracting to pay his indebtedness by labor or service, and subject like any other contractor to an action for damages for breach of that contract, can elect at any time to break it, and no law or force compels performance or a continuance of the service. ${ }^{" 40}$ Even though an employer may hold the prospect of contract damages over a worker's head to compel the worker not to quit, the resulting coercion is either assumed to be too small to violate the Involuntary Servitude Clause, no matter the particular worker's ability to pay, ${ }^{41}$ or is deemed ignorable so that at least some kind of legal coercion remains to back up service contracts.

What justifies this premise? Bailey and its progeny are basically silent, despite Justice Holmes' dissent in Bailey on this very point. ${ }^{42}$ Nonetheless, some courts extend this premise from contract damages to damages generally. ${ }^{43}$ In contrast, Shaw and Thompson concerned damages liability for

39. E.g., Mt. Hawley Ins. Co. v. Lopez, 215 Cal. App. 4th 1385, 1398-1423 (2013) (construing CAL. INS. CODE $§ 533.5(\mathrm{~b})$, which limits insurer duty to defend in criminal actions, not to apply to federal indictments).

40. Clyatt v. United States, 197 U.S. 207, 215 (1905); see also Bailey, 219 U.S. at 242 ("The contract exposes the debtor to liability for the loss due to the breach, but not to enforced labor.")

41. E.g., United States v. Redovan, 656 F. Supp. 121, 129 (E.D. Pa. 1986) (“[I]n assessing damages for breach of a contract, the court is not required to consider the breaching party's ability to pay, in order to stay within constitutional bounds. The fact that the consequences of a large money judgment may encourage [the defendant] to perform a service obligation does not convert him into a peon."), aff'd without op., 826 F.2d 1057 (3d Cir. 1987).

42. Bailey, 219 U.S. at 246-47 (Holmes, J., dissenting).

43. E.g., S.C. Dep't of Health \& Envtl. Control v. Kennedy, 289 S.C. 73 (Ct. App. 1986) (treble damages provision of state statute, authorizing loans to medical and dental students in return for three years' general practice in the medical service area of the state, does not impose involuntary servitude on a physician: "[T]he sanction for breach of his promise is not enforced service as a doctor, but the payment of money damages."); see also United States v. Martin, 710 F. Supp. 271, 275 (C.D. Calif. 1989) (physician plaintiff "not being forced to labor on behalf of plaintiff or any other person or entity," but has "simply exercised his option to trigger the payback provisions of the scholarship contact rather than serve in the NHSC"). On the other hand, Rakoff, supra note 2, at 294, suggests, as a "proper extension of Bailey," a possible rule against "permitting punitive damages to be awarded [against a worker] even for 
new employers that put the worker in a "stay or starve" condition, because any and all new employers would face liability for hiring that worker. In so reasoning, Shaw and Thompson at least implicitly assumed that, for Involuntary Servitude Clause purposes, the worker's job-search geographic scope does not exceed the territorial reach of the challenged law. ${ }^{44}$ Otherwise, the worker could move to a place beyond the law's reach, get a job there (because that law does not reach employers in that place) and thus not starve. ${ }^{45}$ Shaw and Thompson also implicitly assumed that contract law alone was far less likely to put the worker in a stay-or-starve condition, because that law only exposes the quitting worker to contract damages liability, not any of the worker's potential new employers.

Consider an alternative justification for Bailey's second core premisea justification that covers all civil damage awards, not just contract damages: It is hard to collect damage awards against workers. Many are judgmentproof. Legal barriers to collection include limits on wage garnishment, such as those set by Title III of the Consumer Credit Protection Act ${ }^{46}$ as well as more restrictive state laws. ${ }^{47}$ In some states, such limits do not apply to criminal restitution orders, ${ }^{48}$ which are enforced by the contempt power.

an intentional breach of an employment contract," because "such a remedy would make the pressure not to quit too great."

44. On whether a State's statutes and common law typically do or should apply outside that State's territory, see generally Jeffrey A. Meyer, Extraterritorial Common Law: Does the Common Law Apply Abroad?, 102 GEO. L. J. 301, 330-50 (2014).

45. This premise is not the same as a feature of the general "mitigation" rule that, for calculating lost wages owed to plaintiff-worker for an illegal firing, the plaintiff must have acted reasonably to search for and, if available, accept suitable work. For discussion, see Howard C. Eglit, Damages Mitigation Doctrine in the Statutory Anti-Discrimination Context: Mitigating Its Negative Impact, 69 U. CIN. L. REV. $7,35-36$ (2000), who traces this rule to nineteenth-century judges' worries about, and moral disapproval of, worker indolence. Judges applying this rule tend not to require plaintiffs to search for and accept jobs outside the same or similar line of business to the worker's prior job, or jobs that are too far away in distance. See William H. Danne, Jr., Annotation, Nature of Alternative Employment Which Employee Must Accept to Minimize Damages for Wrongful Discharge, 44 A.L.R.3d 629, §§ 4-7 (1972 \& Supp. 2019) (collecting cases).

46. 15 U.S.C. $§ 1673$ (a) (restricts garnished amount to lesser of twenty-five percent of debtor's weekly disposable earnings, or amount of other disposable earnings in excess of thirty times the federal minimum hourly wage).

47. E.g., TEX. PROP. CODE ANN. § 42.001(b)(1) (exempting from garnishment "current wages for personal services, except for the enforcement of court-ordered child support payments"); FLA. STAT. ANN. $\S 222.11(2)$ (b) (prohibits wage garnishment unless debtor consents); N.Y. C.P.L.R. 5231(b) ("not more than ten percent"); see generally 4 EMP. COORD. COMP. §§ 34:121-34:395 (West 2020) (survey of state garnishment laws).

48. E.g., Ala. CODE § 15-18-143(a); see also United States v. Jaffee, 417 F.3d 259, 265 (2d Cir. 2005) ("On the face of its language, [15 U.S.C. § 1673] does not apply to an order that simply directs restitution payments and does not restrain the use of specific funds.”); State v. Pulasty, 612 A.2d 952, 958 (N.J. App. Div. 1992) (agreeing with trial judge that "state and federal restraints on garnishment 'do not limit the criminal restitution authority of this court or the collection of that restitution."') 
Other barriers to collection include debt-collection exemptions for some kinds of real and personal property. ${ }^{49}$

This alternative justification, however, does not extend as easily to employers that are corporations or other non-natural persons. Legal limits to wage garnishment are irrelevant, because garnishment applies to an individual's earnings, not corporate earnings. ${ }^{50}$ Similarly, homestead and personal property exemptions to debt collection typically apply only to individuals. ${ }^{51}$ Moreover, businesses often carry commercial liability insurance, though such policies tend to exclude coverage for "intentional acts" or for liability arising out of contract. ${ }^{52}$ Although punitive damages are uninsurable in some states ${ }^{53}$ payments to satisfy a punitive damages award are still deductible as a business expense under federal income tax law. ${ }^{54}$ Thus, if Bailey's second core premise rests on the difficulty of collecting damages awards, that premise more weakly extends to employers that are corporations or other non-natural persons or that can obtain commercial liability insurance.

\section{CASE STUDIES}

Some case outcomes may turn on whether a judge extends Bailey doctrine's premises to employers. To illustrate, we now consider how Involuntary Servitude Clause challenges might render unconstitutional, on their face or as applied, two kinds of laws: (1) labor mobility restrictions of $\mathrm{H}-2$ foreign guest workers; and (2) non-competition agreements (i.e., exclusivity and post-employment non-compete clauses) in service contracts. This section extends previous Involuntary Servitude Clause commentary on such laws. For example, some have argued that labor-mobility restrictions on

49. E.g., CONN. GEN. STAT. §52-352b(a),(t). On the origin of such exemptions, see Paul Goodman, The Emergence of the Homestead Exemption in the United States: Accommodation and Resistance to the Market Revolution, 1840-1880, 80 J. AM. HIST. 470 (1993).

50. E.g., 15 U.S.C. $\$ 1672$ (c) (defining "garnishment" to mean "any legal or equitable procedure through which the earnings of any individual are required to be withheld for payment of any debt") (emphasis added).

51. E.g., CONN. GEN. STAT. § 52-352b ("The following property of any natural person shall be exempt False") (emphasis added); ARIZ. REV. STAT. § 33-1121(a) (defining "debtor" to mean "an individual whether married or single utilizing property described in this article for personal, family or household use") (emphasis added).

52. E.g., Radianse, Inc. v. Twin City Fire Ins. Co., No. 10-10120-RGS, 2010 WL 3928620 (D. Mass. Oct. 6, 2010); Liberty Corporate Capital Ltd. v. Security Safe Outlet, Inc., 937 F. Supp. 2d 891, 903 (E.D. Ky. 2013) ("Without Denninghoff's breach of his Non-Compete Agreement, SSO would have no information. Accordingly, the Court finds that, under the clear and unambiguous language of the breach of contract exclusion, there is no coverage under the "personal and advertising injury" provisions of the Policy for the trade secret misappropriation claim.")

53. RANDY J. MANILOFF \& JeFFREY W. STEMPEL, 1 General LiabiLITY INSURANCE COVERAGE: KEY ISSUES IN EVERY STATE $§ 20.01$ (4th ed. 2018).

54. Rev. Rul. 80-211, 1980-2 C.B. 57, 58. 
H-2 guest workers violate the Involuntary Servitude Clause, because such workers face deportation if they quit. ${ }^{55}$ These commentators do not mention the penalties faced by the new employers for hiring those $\mathrm{H}-2$ workers if they do quit. Similarly, prior commentators have discussed Involuntary Servitude Clause objections to enforcing non-competition clauses. ${ }^{56}$ They have not discussed why it matters if employers face injunctions or damages for hiring a worker who, by taking that job, thereby breaches a non-competition clause.

\section{A. Case Study: H-2 Workers}

This section illustrates how workers and employers could use the Involuntary Servitude Clause to challenge the laws that limit the mobility of foreign guest workers with $\mathrm{H}-2$ and other visas by effectively tying each worker's visa to a single employer. Such a challenge would focus not only on how such law makes such workers less likely to quit and work for someone else during their authorized stay in the United States. That challenge would also focus on how federal law authorizes criminal sanctions against any employer who employs those workers while that employer's new visa petition for those workers, though filed, has not yet been approved.

$\mathrm{H}-2$ foreign guest workers are non-immigrants with visas to work in the U.S. temporarily as either agricultural workers ( $\mathrm{H}-2 \mathrm{~A}$ visas) or as nonagricultural workers (H-2B visas). ${ }^{57}$ To obtain a H-2 visa, the worker's putative U.S. employer must petition U.S. Citizenship and Immigration Services (USCIS) to approve the H-2 visa for that worker based on that visa's eligibility criteria. ${ }^{58}$ During their authorized temporary stay in the U.S., H-2 workers can only work for that employer. Absent certain exceptions, if an $\mathrm{H}$ 2 worker quits before their visa expires, they are now deportable, unless a

55. See generally Maria L. Ontiveros, Noncitizen Immigrant Labor and the Thirteenth Amendment: Challenging Guest Worker Programs, 38 U. ToL. L. REV. 923 (2007); Kimi Jackson, Farmworkers, Nonimmigration Policy, Involuntary Servitude, and a Look at the Sheepherding Industry, 76 CHI.KENT L. REV. 1271 (2000).

56. See, e.g., Ayesha Bell Hardaway, The Paradox of the Right to Contract: Noncompete Agreements as Thirteenth Amendment Violations, 39 SEATTLE U. L. REV. 957 (2016); Stevens, supra note 36.

57. 8 U.S.C. $§ 1101(\mathrm{a})(15)(\mathrm{H})(\mathrm{ii})$.

58. For example, for USCIS to approve an employer's H-2B petition, the Department of Labor (DOL), through its Wage and Hour Division, must first approve a temporary labor certification for that petition. By that certification, DOL advises USCIS that, as required by statute, see 8 U.S.C. $\S \S$ 1101(a)(15)(H)(ii)(b), 1184(c)(1), a qualified U.S. worker is not available to fill the petitioning employer's job opportunity and that employing the foreign worker will neither reduce wages or nor adversely affect working conditions of similarly employed U.S. workers, see 8 C.F.R. § 214.2(h)(6)(iii)(A),(D). On the petition process for H-2 workers, see generally AUSTIN T. FRAGOMEN, JR., CAREEN SHANNON \& DANIEL MONTALVO, 1 IMMIGRATION LAW \& BUSINESS ch. 7 (2d ed. 2019). 
new prospective employer had already filed, and USCIS had already approved, a new H-2 visa petition for that worker. ${ }^{59}$

Thus, before quitting the current employer, that worker must convince the prospective new employer to (1) incur the cost of preparing and filing a new H-2 visa petition (and supporting documents) for that worker, and (2) wait to fill that position until USCIS decides the petition. If $\mathrm{H}-2$ petitions were costless to file and instantly decided by USCIS, this requirement would not affect $\mathrm{H}-2$ worker quits. That is not the case. ${ }^{60}$ Given the burden associated with H-2 petition filing and approval, H-2 workers, fearing deportation, may remain with their current employer when they would otherwise quit and work for another employer in the U.S. And we might expect this effect on worker quits to increase as the burden to secure a new $\mathrm{H}-2$ visa rises.

The U.S. government, however, cannot justify tying every H-2 worker to a single employer in this way on the ground that it is the best way to bind any new employer to the $\mathrm{H}-2$ visa's eligibility rules. To the contrary, some $\mathrm{H}$-visas are already portable., i.e., workers holding those visas may quit and begin working for a new employer immediately, without becoming deportable, if that employer has filed a non-frivolous petition with USCIS to hire that worker.

Consider three examples. First, since 2000, H-1B visas (for working in the U.S. in certain high-skill "specialty occupations") have been portable. ${ }^{61}$ The H1-B portability provisions - part of the original Senate bill that Congress ultimately enacted ${ }^{62}$ — was a "response to concerns raised about the potential for exploitation of H-1B visa holders as a result of a specific U.S. employer's control over the employee's legal status." ${ }^{63}$

59. 8 C.F.R. $§ 214.2(\mathrm{~h})(2)(\mathrm{i})(\mathrm{D}) ; 8$ C.F.R. $§ 274 \mathrm{a} .12(\mathrm{~b})(9)$; see also Valles-Diera v. Lynch, 659 Fed. Appx. 480 (10th Cir. 2016) (denying review of deportation order of H-2A worker for working for employers other than petitioning employer). In general, “[a]ny alien who was admitted as a nonimmigrant and who has failed to maintain the nonimmigrant status in which the alien was admitted ... or to comply with the conditions of any such status, is deportable." 8 U.S.C. $\S 1227(a)(1)(C)(i)$.

60. E.g., 8 C.F.R. $\S 103.7(\mathrm{~b})(1)(\mathrm{i})(\mathrm{I})$ (USCIS base filing fee); see also id. $\S 103.7(\mathrm{~b})(1)(\mathrm{i})(\mathrm{HHH})$ (fraud detection fee for $\mathrm{H}-2 \mathrm{~B}$ petitions). On the burdens of the petition process, see supra note 58. For a recent Department of Homeland Security estimate of total per-petition filing cost (filing fees and opportunity cost of time to complete the petition), see Exercise of Time-Limited Authority To Increase the Fiscal Year 2019 Numerical Limitation for the H-2B Temporary Nonagricultural Worker Program, 84 Fed. Reg. 20005, 20016 (May 8, 2019) (“\$658.05 if HR specialists file, \$934.10 if an in-house lawyer files, and $\$ 1,271.82$ if an outsourced lawyer files the form").

61. American Competitiveness in the Twenty-first Century Act of 2000, Pub L. No. 106-313, § 105, 114 Stat. 1251 (Oct. 7, 2000), codified at 8 U.S.C. $\$ 1184(n)$.

62. S. 2045, 106th Cong. (Feb. 9, 2000).

63. S. Rep. No. 106-260, at 22-23 (2000). By referring only to "potential" exploitation, the Senate Committee avoided expressly stating that, absent such portability, exploitation in fact tended to occur. To the contrary, the Committee asserted that portability only "further facilitated" already-existing job flexibility: "[T]he market would not tolerate exploitation, especially given the fierce competition for skilled workers. An H-1B employee ... can easily be petitioned by another employer and switch to work 
Second, since 2008, H-2A (agricultural) workers have had, by Department of Homeland Security (DHS) rule, similar portability that applies only if the new employer is enrolled in the federal government's E-Verify program. ${ }^{64}$ DHS explained that conditioning portability on E-Verify enrollment encourages agricultural employers to enroll into E-Verify, and thus reduces the hiring of undocumented workers in the agriculture industry. ${ }^{65}$ DHS also stressed that such limited portability would not induce a worker

to breach his work contract and to change employers prior to fulfillment of the contractual obligations,.... Even if this provision acted as an inducement for some aliens to change employers before completion of the first job (e.g., to get a higher paying job), DHS believes that the overall benefit [of this limited portability] to the agricultural industry, the alien worker, and the U.S. public ... outweighs the possibility of abuse of this privilege by the alien worker or the new petitioning employer. ${ }^{66}$

Third, since 1997, when an H-2B professional athlete "is traded from one organization to another organization," if that athlete files a new petition for H-2B status with the other organization (i.e., their new employer), then the athlete can work for that new organization while that petition is pending. ${ }^{67}$ The Immigration and Naturalization Service, the predecessor agency to DHS, explained that this rule codified a "longstanding" policy it had adopted because "a single athlete can have a significant impact on a team's performance," and given "the length of time required to process certain I-129 petitions." ${ }^{\circ 8}$

Now, suppose an $\mathrm{H}-2$ worker or their prospective new employer challenge the non-portability of $\mathrm{H}-2$ visas as violating the Involuntary Servitude Clause. Since U.S. immigration law first authorized deportation ${ }^{69}$ and created categories of deportable workers ${ }^{70}$ deportable workers have worried that, if they quit, their employers will report them to immigration

\footnotetext{
for that employer.... [S] uch job changes are fairly common among $\mathrm{H}-1 \mathrm{~B}$ workers ...." Id. at 13 (emphasis added); see also Retention of EB-1, EB-2, and EB-3 Immigrant Workers and Program Improvements Affecting High-Skilled Nonimmigrant Workers, 81 Fed. Reg. 82398, 82441 (Nov. 18, 2016) ("the ameliorative purpose of section 214(n) [is] to enhance the job flexibility of $\mathrm{H}-1 \mathrm{~B}$ nonimmigrant workers and minimize the potential exploitation of such workers by employers").

64. 8 C.F.R. $\$ 274 a .12(b)(21)(2020)$.

65. Changes to Requirements Affecting H-2A Nonimmigrants, 73 Fed. Reg. 76891, 76905 (Dec. 18, 2008).

66. Id.

67. 8 C.F.R. § 274a.12(b)(9); see also id. § 274a.12(b)(14) (same for athlete with P-1 visa).

68. Foreign Employers Seeking To Employ Temporary Alien Workers in the H, O, and $\mathrm{P}$ Nonimmigrant Classifications, 62 Fed. Reg. 18508, 18509 (Apr. 17, 1997).

69. See generally TORRIE HeSter, Deportation: The Origins of U.S. POlicy (2017).

70. See generally Gabrielle E. Clark, Coercion and Contract at the Margins: Deportable Labor and the Laws of Employment Termination Under US Capitalism (1942-2015), 43 LAW \& SOC. INQUIRY 618 (2016).
} 
officials for deportation, much as the court in Bailey observed that employers could hold the criminal statute challenged there "over the heads of laborers" to compel them to keeping working for that employer. ${ }^{71}$

At first blush, however, neither of the core premises of Bailey doctrine apply. Although deportation differs in kind from damages liability, neither deportation nor physical detention incident to deportation count as a criminal sanction under current U.S. constitutional doctrine. Supreme Court precedent, originating with Fong Yue Ting v. United States (1893), currently treats laws authorizing deportation of a non-citizen as "not a punishment for crime" for purposes of the Fifth Amendment's Due Process Clause. ${ }^{72}$ Dissenting in Fong Yue Ting, Justice Brewer took the opposite view: "Every one knows that to be forcibly taken away from home, and family, and friends, and business, and property, and sent across the ocean to a distant land, is punishment, and that oftentimes most severe and cruel." ${ }^{, 73}$ More recent cases have held that deportation, though still not a criminal sanction, is still such a "particularly severe penalty" when a collateral consequence of a criminal conviction, that the Sixth Amendment entitles criminal defendants to be advised of that possibility. ${ }^{74}$

To be sure, an employer who threatens a worker with deportation may thereby violate certain federal criminal statutes that Congress enacted pursuant to its power under section 2 of the Thirteenth Amendment to "enforce" that Amendment's Involuntary Servitude Clause by "appropriate legislation." " the abuse-of-legal-process provisions of the Trafficking Victims Protection Act of $2000 .{ }^{77}$ Rulings under these statutes, however, do not necessarily

71. Bailey, 219 U.S. at 245.

72. Fong Yue Ting v. United States, 149 U.S. 698, 730 (1893).

73. Id. at 740 (Brewer, J., dissenting); see also id. at 758-59 (Field, J., dissenting); id. at 763 (Fuller, J., dissenting).

74. Padilla v. Kentucky, 599 U.S. 356, 365 (2010). At least two jurisdictions go further and read the Sixth Amendment to entitle criminal defendants to a right to a jury trial if charged with a crime that, upon conviction, would make that defendant deportable. People v. Suazo, 118 N.E.3d 168 (N.Y. 2018); Bado v. United States, 186 A.3d 1243 (D.C. 2018).

75. U.S. CONST. amend. XIII, § 2 .

76. 18 U.S.C. $\S 1584$ (crime for anyone who "knowingly and willfully holds to involuntary servitude" anyone else); United States v. Shackney, 333 F.2d 475, 486-87 (2d Cir. 1964) (employer deportation-threat cases not violate $\S 1584$, "at least absent circumstances which would make such deportation equivalent to imprisonment or worse"); accord Zavala v. Wal-Mart Stores, 691 F.3d 527, 541 (3d Cir. 2012); cf. United States v. Kozminski, 487 U.S. 931, 948 (1988) (reading section 1584 to incorporate how most courts by 1948 had read the Involuntary Servitude clause - to require at least the threat of physical or legal coercion to compel labor - but noting it was "possible that threatening ... an immigrant with deportation could constitute the threat of legal coercion that induces involuntary servitude" under the statute).

77. Pub. L. No. 106-386, § 112(a), 114 Stat. 1464, codified as amended, 18 U.S.C. § 1589(3) (anyone "knowingly ... obtains the labor or services of a person by ... by means of the abuse or threatened abuse of law or legal process"); United States v. Kaufman, 546 F.3d 1242, 1261 (10th Cir. 
imply the scope of the Involuntary Servitude Clause itself, because section 2 of the Thirteenth Amendment authorizes Congress to do more (and, by implication, less) to "enforce" the Involuntary Servitude Clause than what that Clause prohibits on its own. ${ }^{78}$

Accordingly, to challenge an $\mathrm{H}-2$ visa's non-portability, the $\mathrm{H}-2$ worker's lawyer must directly argue for extending Bailey and its progeny to recognize a new covering premise: For any challenged law, if that law effectively authorizes deportation against workers for quitting, then we assume that law adversely affects worker quits enough to create "involuntary servitude" in the run of cases that law covers. It is, however, hard to estimate directly how much the non-portability rule for $\mathrm{H}-2 \mathrm{~B}$ workers tends to affect worker quits, all else equal. Despite reports consistent with the new premise,${ }^{79}$ there is no obvious proxy for the counterfactual world in which $\mathrm{H}$ 2 visas are all portable. Moreover, some judges may fear that, by adopting this premise, they would undermine Fong Yue Ting and thus make more likely something those judges may not want, i.e., deportees with the same Fifth Amendment procedural protections as federal criminal defendants.

Thus far, however, we have only considered one path by which the law requiring $\mathrm{H}-2$ visa non-portability affects the odds they will quit their current employer: by making H-2 workers deportable (Figure 1: $X \rightarrow Q$ ). We now also consider the effect related legal restrictions on employer hiring (Figure 1: $X \rightarrow J \rightarrow Q$ ). Once H-2 workers are deportable for quitting, anyone who employs them after they quit are exposed to civil penalties, injunctive relief, and criminal penalties, because in 1986, Congress enacted the Immigration Reform Control Act (IRCA), which authorizes such penalties against any person who knowingly hires or continues to employ an individual not authorized to work in the U.S. ${ }^{80}$ This matters because, under Bailey and progeny, a challenged law is unduly coercive if it authorizes criminal

2008) (“[I]n enacting $§ 1589$, Congress sought to expand Kozminski’s limited definition of coercion under $\S 1584$, stating that ' [s]ection 1589 will provide federal prosecutors with the tools to combat severe forms of worker exploitation that do not rise to the level of involuntary servitude as defined in Kozminski.' See H.R. Conf. Rep. No. 106-939, at 101, as reprinted in 2000 U.S.C.C.A.N. 1380, 1393.”); see United States v. Calimlim, 538 F.3d 706, 713 (7th Cir. 2008) (\$ 1589(3) can cover threats of deportation); see also Claudia G. Catalano, Annotation, Validity, Construction, and Application of Section 112 of Trafficking Victims Protection Act of 2000 and Subsequent Reauthorizing Provisions amending Chapter 77 of Title 18, United States Code, 75 A.L.R. Fed. 2d 467, § 22 (2013 \& Supp. 2020) (collecting cases).

78. Jones v. Alfred H. Mayer Co., 392 U.S. 409, 439-40 (1968). For discussion of that power, see Jennifer Mason McAward, The Scope of Congress' Thirteenth Amendment Enforcement Power After City of Boerne v. Flores, 88 WASH. U. L. REV. 77 (2010).

79. E.g., MARy BAuer, SOUthern POVERTy Law CEnTER, Close to SlaVery: Guestworker PROGRAMS IN THE UNITED STATES (2013).

80. Immigration Reform and Control Act of 1986, Pub L. No. 99-604, § 101, 100 Stat. 3359, 3360, codified as amended, 8 U.S.C. $\S 1324 \mathrm{a}(\mathrm{a})(1)(\mathrm{A})$, (2); see 8 U.S.C. $\S \S 1324 \mathrm{a}(\mathrm{e})(4)$ (civil penalties), $1324 \mathrm{a}(\mathrm{f})(1)$ (criminal penalties), 1324a(f)(2) (injunctive relief). 
sanctions for quitting. If that premise extends to employers, then a judge must assume in any case (not treat as an issue of fact) that IRCA, simply by authorizing criminal sanctions for hiring deportable $\mathrm{H}-2$ workers, unduly reduces worker quits indirectly by reducing the odds of new employers hiring them.

Thus, to fully account for how H-2 visa non-portability affects worker quits, judges must consider both IRCA's authorization of criminal sanctions on hiring employers and immigration law's authorization of deportation of the quitting workers. In contrast, if the workers were already deportable before they quit, the non-portability rule does not itself affect worker quits, because it is not the quit itself that makes those workers deportable. While new employers who hire them would still risk penalties, those workers were no more deportable after the quit than before.

This argument, however, if taken seriously, may apply not just to $\mathrm{H}-2$ workers, but also to other non-immigrant workers with non-portable visas who may only work for the "specific employer" that obtained that worker's visa (for some examples, see Table 1). ${ }^{81}$

Table 1

\begin{tabular}{ll} 
Visa & Type \\
\hline A-1, A-2 & foreign government official \\
\hline E-1, E-2 & treaty trader, treaty investor \\
\hline H-2A & temporary worker (agricultural) \\
\hline H-2B & temporary worker (other) \\
\hline H-3 & trainee \\
\hline I & information media representative \\
\hline J-1 & exchange visitor \\
\hline L & intra-company transferee \\
\hline NATO-1 to & NATO-employed, \\
\hline O-1 & NATO-member-nation armed services \\
\hline P-1, P-2, P-3 & extraordinary ability \\
\hline Q-1 & artist, entertainer, athlete \\
\hline R-1 & international cultural exchange visitor \\
\hline & alien having religious occupation
\end{tabular}

That is because IRCA's authorization of criminal sanctions on employers applies to any "person or other entity" 82 who knowingly hires any

81. 8 C.F.R. $§ 274 a .12$ (b) (2020) (setting forth "classes of aliens . . . authorized to be employed in the United States by the specific employer ....”).

82. 8 U.S.C. $\S 1324 a(a)(1)$. Because this provision is in subchapter II of Chapter 12 of the U.S. Code, "[t]he term 'person' means "an individual or an organization." 8 U.S.C. $§ 1101(b)(3)$ (defining 
"unauthorized alien," and that includes hiring any worker who, because of visa non-portability, became deportable when they quit. ${ }^{83}$ Thus, if any such visa has no portability, that violates the Involuntary Servitude Clause, because IRCA authorizes criminal sanctions against any person who knowingly hires a worker who held that visa and, upon quitting, became deportable.

This argument implies that the Involuntary Servitude Clause requires a certain kind of minimum portability: Anyone with any non-immigrant visa tied to specific employer must be able to quit and begin working for a new employer immediately, without becoming deportable, if that new employer has already filed a non-frivolous petition with USCIS to hire that worker. This is the portability that H1-B workers and some $\mathrm{H}-2 \mathrm{~A}$ workers already have ${ }^{84}$ On its face, this kind of minimum portability accords with at least two reasons why the U.S. government may want to tie any non-immigrant worker's visa to a single employer: (1) to hold the new employer to the same eligibility restrictions that justified approving the first employer's petition for the worker's visa; and (2) to hold accountable the person (i.e., the new employer) who is in the best position to keep track of the worker's location in the U.S. for the rest of that worker's authorized period of stay. To be sure, if a law affording such minimum portability on its face was, in practice, really no different in its effect on worker quits than a law affording no portability at all, then both workers and prospective employers could seek redress by way of an as-applied Involuntary Servitude Clause challenge.

Finally, consider how workers and prospective employers could challenge H-2 visa-non-portability as violating the Involuntary Servitude Clause: by filing a declaratory judgment action. In any such action, H-2 workers who want to quit to work for a new employer have the requisite standing, as do prospective employers who want to hire such workers but fear IRCA sanctions for doing so. To be sure, if, after filing suit, a worker's original H-2 visa has already expired, as is likely for such short-duration visas, the government will likely seek to dismiss the suit for mootness. In turn, this would raise the issue of whether a court should accept the mootness-

\footnotetext{
"person" "as used in subchapters I and II"). In turn, “[t]he term 'organization' means, but is not limited to, an organization, corporation, company, partnership, association, trust, foundation or fund; and includes a group of persons, whether or not incorporated, permanently or temporarily associated together with joint action on any subject or subjects." $I d$. $\S 1101$ (a)(28) (defining "organization" "[a]s used in this chapter"); see 8 C.F.R. $\$ 313.1$ (same).

83. 8 U.S.C. $\$ 1324 a(h)(3)$ (defining "unauthorized alien").

84. This argument is not the same as a Fifth Amendment claim that Congress and DHS have no rational basis for denying portability to $\mathrm{H}-2 \mathrm{~B}$ workers while granting some portability to H1-B workers and some $\mathrm{H}-2 \mathrm{~A}$ workers.
} 
doctrine exception for disputes that tend to recur yet evade review. ${ }^{85}$ On that issue, it may be easier for the prospective employer, rather than the worker, to show that the dispute is likely to recur. That employer would have to show that it will likely have another occasion to hire another H-2 worker under similar circumstances. In contrast, the H-2 worker would have to show that they are likely to return to the U.S. on another $\mathrm{H}-2$ visa and face the same situation of wanting to quit to work for another employer in the U.S.

Moreover, if workers press this constitutional argument to challenge their removal (deportation), they face distinctive procedural obstacles. According to the Board of Immigration Appeals, immigration judges (who issue removal orders) as well as the Board itself, lack the authority to decide that federal immigration statutes and regulations violate the U.S. Constitution ${ }^{86}$ In addition, any judicial review of a final order of removal's validity can be decided only and exclusively via a petition to an appropriate federal court of appeal under restrictive conditions of review. ${ }^{87}$ Such limited judicial review covers "all questions of law and fact, including interpretation and application of constitutional and statutory provisions, arising from any action taken or proceeding brought to remove an alien from the United States." $" 88$

These limitations, however, would not apply to an employer's declaratory judgment action asserting a facial constitutional challenge to the law barring $\mathrm{H}-2$ visa portability. A facial challenge by definition ${ }^{89}$ does not require the government to have applied the $\mathrm{H}-2$ non-portability rule by taking any action, or bringing any proceeding, to remove an $\mathrm{H}-2$ visa holder who quits to work for another employer. In addition, such prospective employers are not themselves subject to removal because they hired that $\mathrm{H}-2$ visa holder. For that reason, those limited judicial review provisions would not affect the Involuntary Servitude Clause challenges those employers bring.

85. See generally Charles Allen Wright et al., 13C Federal Practice \& Procedure: JURISDICTION $§ 3533.8$ (3d ed. 2019) ("Events or orders defined by time often present cyclical or recurring disputes that generate capable-of repetition decisions.")

86. See generally Alina Das, Administrative Constitutionalism in Immigration Law, 98 B.U. L. REV. 485, 506-514 (2018); see also 8 C.F.R. § 1003.1(d)(1) (requiring Board to resolve questions before it "consistent with the Act and regulations"); id. §1003.10(d) ("Immigration judges shall be governed by the provisions and limitations prescribed by the Act and this chapter, by the decisions of the Board, and by the Attorney General (through review of a decision of the Board, by written order, or by determination and ruling pursuant to section 103 of the Act).").

87. See 8 U.S.C. § 1252(a)(1), (5); id. § 1252(b)(4).

88. 8 U.S.C. $§ 1252(b)(9)$.

89. A facial challenge to a statute or regulation seeks a judicial declaration that the statute or regulation is unconstitutional in every conceivable application in which it authorizes or prohibits conduct. City of Los Angeles v. Patel, 135 S. Ct. 2443, 2449 (2015); accord Washington State Grange v. Washington State Republican Party, 552 U.S. 442, 449 (2008); United States v. Salerno, 481 U.S. 739, 751 (1987). 
To recap, once we extend Bailey doctrine's first core premise to employers, and given that IRCA authorizes criminal sanctions against employers for knowingly employing unauthorized workers, the Involuntary Servitude Clause at least requires that any non-immigrant-visa holder, if tied to specific employer, can quit and work for a new employer immediately, without becoming deportable, provided a new visa petition for that worker is already filed and pending. Just as importantly, prospective new employers themselves may challenge visa non-portability on this basis and, in doing so, face fewer procedural hurdles than $\mathrm{H}-2$ workers would.

\section{B. Case Study: Non-Competition Agreements}

Here, we consider how extending Bailey doctrine's core premises to employers affects Involuntary Servitude Clause challenges to two kinds of employment contract clauses that restrict labor mobility: exclusivity clauses and post-employment non-competition clauses (collectively "CNCs"). The analysis depends on the remedy sought in suits to enforce CNCs. Because all injunctions are backed by criminal contempt, Bailey's first premise can extend to injunctions to enforce CNCs against workers and the actual or prospective new employers who do or might hire them. In contrast, for lawsuits to enforce CNCs that seek only damages, how far Bailey's second premise extends is less clear.

An exclusivity clause provides that, for the contract's duration, person A promises to provide a certain service to person B and no one else within a geographic area and time period. The classic example is a theater or concert venue that contracts with a performer to perform only at that venue for a certain time period..$^{90}$ In contrast, a post-employment non-competition clause imposes a time and geographic restriction only after the worker exits the counterparty's (now former employer's) employ. ${ }^{91}$

Both kinds of CNCs share a key feature: If the worker violates either type of clause, the counterparty-employer may seek not only contract damages, but also a "negative injunction" to enforce the clause, i.e., a court order (enforceable by contempt sanction) that the worker not work for anyone else in violation of the CNC. For Involuntary Servitude Clause analysis, however, many judges seem to reason that, unlike specific performance orders, an injunction to enforce a CNC is not too coercive, because of a "some

90. See generally 25 WILLISTON ON CONTRACTS $§ 67: 108$ (4th ed. 2019) (collecting cases).

91. For how state law varies on enforcing CNCs, see generally CovENANTS NOT TO COMPETE: A State-By-STAte Survey (Brian M. Malsberger ed., 12th ed. 2018). For a review of the empirical literature on how much non-compete clauses affect labor turnover, see Norman Bishara \& Evan P. Starr, The Incomplete Noncompete Picture, 20 LEWIS \& CLARK L. REV. 497 (2016). 
job" rationale: the CNC still permits the worker to get some kind of new job, even if not in the same place or industry. ${ }^{92}$

This argument is weak. Judges have criminal contempt power to enforce $\mathrm{CNC}$ injunctions just as they do to enforce specific performance decrees or any other type of injunctions. ${ }^{93}$ Thus, Bailey and its progeny's factual premise for criminal sanctions applies as a substitute for directly estimating a CNC injunction's effect on worker quits. This holds regardless of, as some have stressed, whether CNC-enforcing injunctions only tell workers what not to do, ${ }^{94}$ or otherwise do not affect work quits as much as specific-performance decrees. ${ }^{95}$

To see why, suppose the criminal fraud statute challenged in Bailey provided that the statute did not apply if the worker, after quitting, started a new job as a ditch-digger. Suppose further that, absent that statute, most workers like Bailey would have searched for a job other than ditch-digging jobs. Would the Bailey court have concluded that the challenged statute's criminal sanctions would not unduly affect worker quits, just because workers otherwise subject to it could have avoided that sanction by getting a ditch-digging job? No. In both cases, Bailey's premise about criminal sanction holds. The worker is exposed to possible criminal sanctions for quitting in a certain way: quitting without paying back a salary advance (as in Bailey) or quitting and taking a new job that violates a CNC's occupational restriction. Indeed, the "some job" rationale is weaker still where that job

92. Apperson v. Ampad Corp., 641 F. Supp. 747, 751 (N.D. Ill. 1986) (no Thirteenth Amendment claim because plaintiff "retains the right to pursue employment in other industries besides paper goods"; see also Flood v. Kuhn, 443 F.2d 264, 286 (2d Cir. 1971) (no Thirteenth Amendment claim "[i]nasmuch as plaintiff retains the option not to play baseball at all"). For courts that distinguish specific performance from CNC-enforcing injunctions without any explanation, see, e.g., In re Andrews, 80 F.3d 906, 912 (4th Cir. 1996); Cropper v. Davis, 243 F. 310, 316 (8th Cir. 1917); and In re Bluman, 125 B.R. 359, 367 (Bankr. E.D.N.Y. 1991). Courts that have opined to the contrary do not expressly address this argument. See, e.g., Kadis v. Britt, 29 S.E.2d 543, 549 (N.C. 1944) ("Injunction will not, of course, issue to compel the performance of the affirmative promise of service, because that would result in involuntary servitude; and for the same reason, it will not interfere to enforce the negative covenant when the apparent purpose and effect is to enforce the affirmative promise to perform duties of the employment.") (citation omitted). In Beverly Glen Music v. Warner Communications, 224 Cal. Rptr. at 261, the court in dicta appeared to both accept and criticize the legal distinction: "[W]hile it is not possible to compel a defendant to perform his duties under a personal service contract [without violating Involuntary Servitude Clause], it is possible [at common law] to prevent him from employing his talents anywhere else. The net effect is to pressure the defendant to return voluntarily to his employer by denying him the means of earning a living. Indeed, this is its only purpose, for, unless the defendant relents and honors the contract, the plaintiff gains nothing from having brought the injunction.").

93. E.g., 18 U.S.C. § 401(3); Mich. COMP. LAWS § 600.1701(g).

94. Stevens, supra note 36 , at 269-70.

95. Rakoff, supra note 2, at 293 , adds that a negative injunction "can properly issue" when "the balance of injury shifts-when the employer can show additional injury from the employee's going beyond just quitting to also working for a competitor." Involuntary Servitude Clause doctrine, however, does not provide that judges may balance the former employer's injury against legal coercion imposed on the worker. See generally Wooster, supra note 1. 
requires the worker to go work in a place that comports with a CNC geographical restriction. Bailey necessarily assumed that the worker jobsearch's geographic scope does not exceed the reach of the challenged law; otherwise, it would have mattered to the Court in Bailey whether someone could have escaped the coercion of the criminal fraud statute simply by leaving Alabama to look for a new employer.

Now, consider not only how the prospect of CNC injunctions (backed by criminal contempt) directly affects how likely a worker is to quit (Figure 1: $X \rightarrow Q$ ), but also how CNC injunctions can affect employer hiring, either by attaching adverse legal consequences to new employers for hiring those workers (Figure 1: $X \rightarrow J \rightarrow Q$ ), or by causing a worker to limit their jobsearch scope in order to comport with the CNC's restrictions (Figure 1: $X \rightarrow$ $S \rightarrow J \rightarrow Q$ ).

Although new employers are not parties to CNCs, they may be enjoined nonetheless for hiring a worker who, by taking the job, thereby violate that worker's CNC, for two main reasons. First, some courts have declared that they may directly enjoin a non-signatory to a CNC upon a showing that that non-signatory has knowingly helped a party to breach the CNC. ${ }^{96}$ Second, even if the court only expressly enjoins the former employee, a court can easily conclude that her new employer is thereby enjoined. In hiring that former employee, the new employer acts "in active concert or participation" with the enjoined former employee within the meaning of Federal Rule of Civil Procedure 65 and state law equivalents, which specify who besides the enjoined named parties are bound thereby.$^{97}$ If so, the same grounds for extending Bailey and its progeny to CNC-enforcing injunctions - that they subject those enjoined to criminal sanctions - apply with equal force to the enjoined new employer.

Thus far, we have assumed a case in which the former employer files suit alleging violation of the $\mathrm{CNC}$ and seeks to enjoin the worker, the new employer, or both. If the former employer has not yet sued anyone based on the $\mathrm{CNC}$, it is a closer question as to whether the new employer could move first and obtain a declaratory judgment that any injunction to enforce the $\mathrm{CNC}$ that bound the new employer, directly or indirectly, would violate the Involuntary Servitude Clause. Under the Declaratory Judgment Act, this

96. E.g., Kasco Services Corp. v. Benson, 831 P.2d 86, 90 (Utah 1992) ("in the appropriate circumstances, a third party may be enjoined if it is shown to be aiding or assisting the covenantor in violating the noncompetition agreement and with knowledge of the covenant"); McCart v. H \& R Block, 470 N.E.2d 756, 760-62 (Ind. Ct. App. 1984).

97. Fed. R. Civ. P. 65(d)(2)(C); Fla. R. Civ. P. 1.610(c); InD. TR. Proc. R. 65(D); Nev. R. Civ. P. 65(d); e.g., Channell v. Applied Research, 472 So.2d 1260 (Fla. Ct. App. 1985) (injunction against former employees for breaching non-compete applied to former employees' new employer, a non-party to the suit, under FLA. R. CiV. P. 1.610(c)). The new employer may also be enjoined if it is the former-employee defendant's alter ego. Temporarily Yours-Temporary Help Services, Inc. v. Manpower, Inc., 377 So. 2d 825 (Fla. Dist. Ct. App. 1979). 
question reduces to whether there is a "case of actual controversy." 98 In contrast, the Uniform Declaratory Judgments Act, adopted in most states, authorizes a declaratory judgment to construe a contract "either before or after there has been a breach thereof." ${ }^{99}$ This question, however, concerns the procedural issue of whether there is enough of a dispute to authorize a federal or state court to hear a declaratory judgment action. This issue should not be confused with the merits of the new employer's arguments under the Involuntary Servitude clause.

Even if the former employer files suit, the analysis is more complicated if a worker faces only damages, not an injunction, for breaching a CNC. For example, Hardaway reads the Involuntary Servitude Clause to prohibit damages awards for breach of CNCs that cover "low wage" workers. ${ }^{100}$ Faced with the judgment debt of a damages award, along with litigation costs incurred, such workers "will be coerced into working [that debt] off, thus subjecting them to peonage." 101 If enforced, she argues, the CNC causes the worker to choose between "continu[ing] to work in undesirable conditions or having no income at all." "102 Indeed, the same reasoning holds for contract damages actions arising under forfeiture-for-competition agreements, under which workers forfeit certain forms of deferred compensation, or must pay back expressly denoted "retention pay," in the event they breach a postemployment CNC. ${ }^{103}$ Whatever its merits, however, this kind of argument is currently foreclosed by Bailey's second core premise: A law that authorizes contract damage awards against workers, and as a result adversely affects worker quits, does not thereby violate the Involuntary Servitude Clause.

98. 28 U.S.C. $\$ 2201$ (a)

99. UNIF. DECLARATORY JUdGMENTS ACt $§ 3$ (1922); see, e.g., Lapolla Indus., Inc. v. Hess, 750 S.E.2d 467, 470-471 (Ga. Ct. App. 2013) (declaratory judgment action available under Georgia law where "in light of the non-compete covenants between Lapolla and the former Lapolla employees in the present case, Premium and Hess were uncertain as to their legal right to continue attempts to hire (or continue to employ) the former Lapolla employees")

100. Hardaway, supra note 56, at 979.

101. Id.

102. Id.

103. Most States subject such agreements to the same statutory or common-law standards governing the enforceability of other non-compete clauses. See, e.g., Deming v. Nationwide Mut. Ins. Co., 905 A.2d 623, 638 (Conn. 2006). On the legal treatment of forfeiture-for-competition clauses provisions in employment contracts, see Donald J. ASPELUnd \& JoAn E. BeCKNER, EMPloyeE NONCOMPETITION LAW $\S \S 9.7,10: 5$ (2019). On penalty clauses as non-competes, see LouIS ALTMAN \& MALLA POLLACK, 2 Callmann on Unfair Competition, TRAdemarks and Monopolies $\S 16: 33 \mathrm{nn}$. 11-14 (4th ed. 2019) (collecting cases). A few States, however, do not. See, e.g., Eastern Carolina Internal Medicine, P.A. v. Faidas, 564 S.E.2d 53 (N.C. App. 2002); Rochester Corp. v. Rochester, 450 F.2d 118 (4th Cir. 1971) (applying Virginia law). For example, New York common law does not require a forfeiture-forcompetition clause to be reasonable, unless the employer had discharged the former employee without cause. Morris v. Schroder Capital Mgt. Intl., 859 N.E.2d 503, 506 (N.Y. 2006); Post v. Merrill Lynch, Pierce, Fenner \& Smith, 397 N.E.2d 358, 360 (N.Y. 1979). 
Less clear is how judges should account for the additional and cumulative effect of a CNC damages action on worker quits by how it affects a new employer's willingness to hire a worker who, if she accepts the job, would breach the CNC. Echoing the fact patterns of Shaw and Thompson, most states recognize tort liability for intentional interference with an employment contract, including by third parties who intend to lead workers to quit in breach of their $\mathrm{CNC}$ and then to work for the third party instead. ${ }^{104}$ Indeed, in some states, a former employer may sue a former worker for breach of a CNC and simultaneously sue that worker's new employer for tortious interference. ${ }^{105}$ Moreover, in some states, the new employer may be secondarily liable for contract damages if they profited from the former worker's breach of the CNC. ${ }^{106}$ Although businesses often carry commercial liability insurance, claims for tortious interference with employment agreements may fall within the coverage exclusion for liability arising out of contract. ${ }^{107}$ How judges resolve this issue largely depends on whether they read Bailey and its progeny's second premise to apply only to contract damages arising from breach of the CNC, or to civil damages generally, as well as whether that premise applies with equal force to corporate or other non-individual employers.

\section{CONCLUSION}

This article has argued that employers can sometimes validly challenge legal restrictions as violating the Thirteenth Amendment's Involuntary Servitude Clause, because the premises of Bailey and its progeny can easily extend to bar legal coercion against new employers who would otherwise hire those workers after they quit. If so, then existing precedent on the Involuntary Servitude Clause would suffice to establish a minimum level of labor mobility in the U.S. that both workers and employer could bring lawsuits to enforce. To illustrate, the article presented arguments that employers as well as workers might use to challenge the labor mobility restrictions on $\mathrm{H}-2$ and other temporary foreign guest workers, as well as to challenge certain kinds

104. E.g., Mattison v. Johnston, 730 P.2d 286, 292 (Ariz. 1986); see generally ToRTIOUS INTERFERENCE IN THE EMPLOYMENT CONTEXT: A STATE-BY-STATE SURVEY (Brian Malsberger ed., 6th ed. 2019); ALtMAN \& POLLACK, supra note 103, at § 9:22.

105. E.g., Synthes, Inc. v. Emerge Medical, Inc., 25 F. Supp. 3d 617 (E.D. Pa. 2014) (applying Pennsylvania law); but cf. Voorhees v. Guyan Machinery Co., 446 S.E.2d 672 (W. Va. 1994) (affirming lower court's finding that former employer's threat to enforce an unenforceable non-competition agreement against the former employee's new employer constituted tortious interference with the former employee's relationship with the new employer).

106. E.g., Platinum Mgmt., Inc. v. Dahms, 666 A.2d 1028, 1046 (N.J. Super. Ct. Law. Div. 1995); Hagen v. American Agency, Inc., 617 N.W.2d 799, 802 (Minn. Ct. App. 2000).

107. E.g., Radianse, Inc. v. Twin City Fire Ins. Co., No. 10-10120-RGS, 2010 WL 3928620 (D. Mass. Oct. 6, 2010); Liberty Corporate Capital Ltd. v. Security Safe Outlet, Inc., 937 F. Supp. 2d 891, 903 (E.D. Ky. 2013). 
of non-competition agreements in labor contracts. To be sure, nothing here suggests that the Involuntary Servitude Clause should be limited to such extensions of Bailey and its progeny. Nor does this article speculate as to how likely judges would accept the reasoning offered here. It does, however, provide reasons for lawyers and judges to start thinking of employers as well as workers as the Involuntary Servitude Clause's potential enforcers. 